University of Nebraska - Lincoln

DigitalCommons@University of Nebraska - Lincoln

Biological Systems Engineering: Papers and

Publications

Biological Systems Engineering

2014

\title{
Seed Tape Effects on Corn Emergence under Greenhouse Conditions
}

\author{
Ramarao Venkatesh \\ The Ohio State University \\ Peter R. Thomison \\ Ohio State University, thomison.1@osu.edu \\ Colette K. Gabriel \\ The Ohio State University \\ Mark A. Bennett \\ The Ohio State University \\ Elaine M. Grassbaugh \\ The Ohio State University
}

See next page for additional authors

Follow this and additional works at: https://digitalcommons.unl.edu/biosysengfacpub

Part of the Bioresource and Agricultural Engineering Commons, Environmental Engineering Commons, and the Other Civil and Environmental Engineering Commons

Venkatesh, Ramarao; Thomison, Peter R.; Gabriel, Colette K.; Bennett, Mark A.; Grassbaugh, Elaine M.;

Kleinhenz, Matthew D.; Shearer, Scott A.; and Pitla, Santosh, "Seed Tape Effects on Corn Emergence under Greenhouse Conditions" (2014). Biological Systems Engineering: Papers and Publications. 464.

https://digitalcommons.unl.edu/biosysengfacpub/464

This Article is brought to you for free and open access by the Biological Systems Engineering at DigitalCommons@University of Nebraska - Lincoln. It has been accepted for inclusion in Biological Systems Engineering: Papers and Publications by an authorized administrator of DigitalCommons@University of Nebraska Lincoln. 


\section{Authors}

Ramarao Venkatesh, Peter R. Thomison, Colette K. Gabriel, Mark A. Bennett, Elaine M. Grassbaugh, Matthew D. Kleinhenz, Scott A. Shearer, and Santosh Pitla 


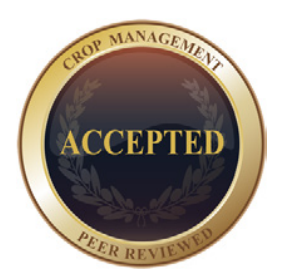

\title{
Seed Tape Effects on Corn Emergence under Greenhouse Conditions
}

\author{
Ramarao Venkatesh, * Peter R. Thomison, Colette K. Gabriel, Mark A. Bennett, \\ Elaine M. Grassbaugh, Matthew D. Kleinhenz, Scott A. Shearer, and Santosh K. Pitla
}

S

EED TAPE has recently received attention as an alternative planting system for smallholder farmers in underdeveloped regions of South America, Africa, China, and India (Mateus, 2014). Seed companies are also developing seed-tape planting systems for germplasm evaluations (Deppermann et al., 2013). Although seed tape has been promoted as a method for ensuring uniform seed spacing and plant density of smallseeded flowers, herbs, and vegetables (Chancellor, 1969), little or no information is available on the use of seed tape for largerseeded row crops and its effect on crop emergence. The objective of this study was to compare the emergence of corn seed embedded in tape to seeds planted by hand and to determine seed tape effects on rate of corn emergence.

Experiments were conducted in 2013 in greenhouses at Ohio State University and consisted of two treatments. Corn seed embedded in tape made of biodegradable cellulose, which is the material most widely used by seed tape manufacturers, was compared with seeds planted by hand. Two corn hybrids were used in the study-Pioneer brand 37Y14 treated with fludioxonil, mefenoxam, azoxystrobin, thiabendaz, and thiamethoxam and DeKalb DKC 65-63 treated with difenoconazole, fludioxonil, mefenoxam, and thiamethoxam.

Seed tape and seeds were hand planted 2 inches deep in flats with commercial top soil (Fig. 1). Greenhouse temperature was maintained at 70 to $75^{\circ} \mathrm{F}$, and metal halide lamps provided approximately $220 \mu \mathrm{mol}^{-1} \mathrm{~m}^{-2} \mathrm{~s}^{-1}$ supplemental photosynthetic photon flux for a $16-\mathrm{h}$ daily photoperiod.

Corn emergence was recorded at the first appearance of coleoptile and monitored for approximately 2 weeks. Mean emergence time (MET) and emergence rate index (ERI) were used to measure how quickly and uniformly the corn emerged after planting. Multiple emergence counts were taken and used to calculate MET and ERI (Karayel and Ozmerzi, 2002). Treatments were arranged in a randomized complete block design replicated three times for each run. The experiment was repeated eight times (total of 24 replications), and a total of 240 seeds was used for each treatment (120
Ramarao Venkatesh, Peter R. Thomison, Colette K. Gabriel, Mark A. Bennett, Elaine M. Grassbaugh, and Matthew D. Kleinhenz, Dep. of Horticulture and Crop Science; and Scott A. Shearer, Dep. of Food, Agricultural and Biological Engineering, Ohio State Univ., Columbus, OH 43210; Santosh K. Pitla, Dep. of Biological Systems Engineering, Univ. of Nebraska-Lincoln, Lincoln, NE 68588. Received 11 June 2014. *Corresponding author (venkatesh.1@ osu.edu).

Conversions: For unit conversions relevant to this article, see Table A.

Published in Crop Management

DOI 10.2134/CM-2014-0051-BR

(C) 2014 American Society of Agronomy

and Crop Science Society of America 5585 Guilford Rd., Madison, WI 53711

All rights reserved. No part of this periodical may be reproduced or transmitted in any form or by any means, electronic or mechanical, including photocopying, recording, or any information storage and retrieval system, without permission in writing from the publisher. Permission for printing and for reprinting the material contained herein has been obtained by the publisher. 
Table A. Useful conversions.

\begin{tabular}{ccc}
\hline $\begin{array}{c}\text { To convert Column } 1 \text { to Column 2, } \\
\text { multiply by }\end{array}$ & $\begin{array}{c}\text { Column } 1 \\
\text { Suggested Unit }\end{array}$ & $\begin{array}{c}\text { Column } 2 \\
\text { SI Unit }\end{array}$ \\
\hline 2.54 & inch & centimeter, $\mathrm{cm}\left(10^{-2} \mathrm{~m}\right)$ \\
$9.29 \times 10^{-2}$ & square foot, sq ft & square meter, sq m \\
$5 / 9\left({ }^{\circ} \mathrm{F}-32\right)$ & Fahrenheit, ${ }^{\circ} \mathrm{F}$ & Celsius, ${ }^{\circ} \mathrm{C}$ \\
\hline
\end{tabular}

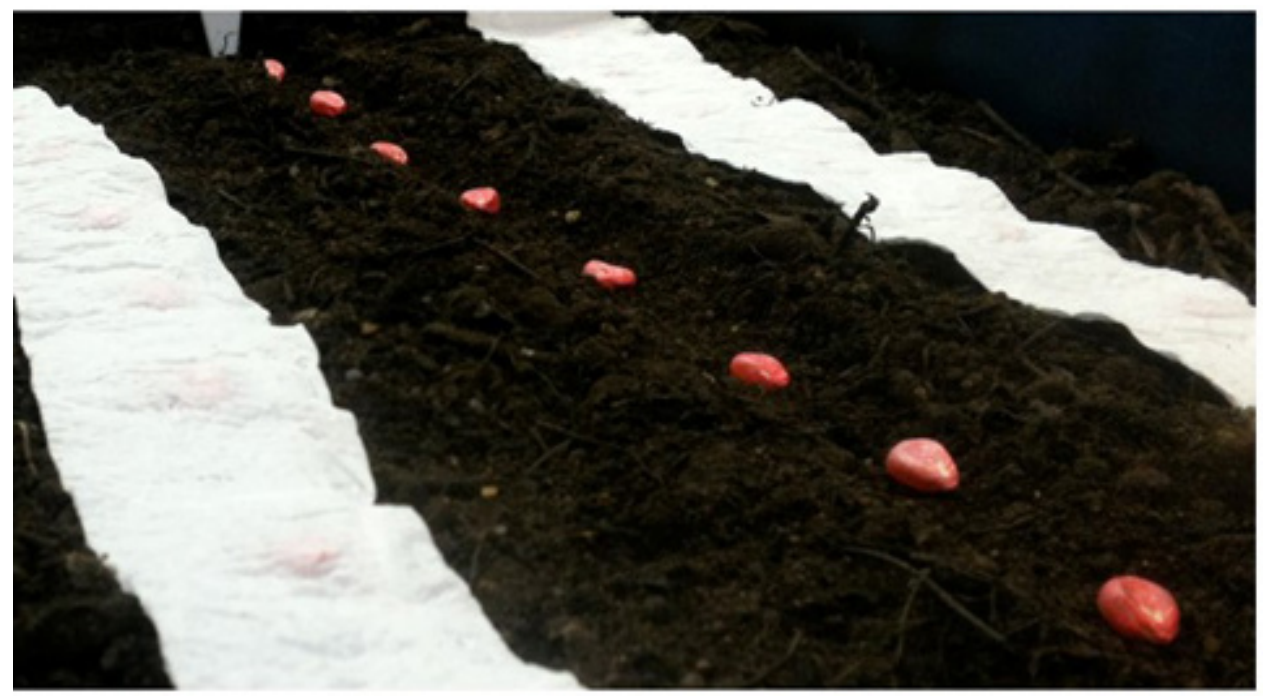

Figure 1. Corn seed embedded in seed tape and seeds planted by hand in the greenhouse.

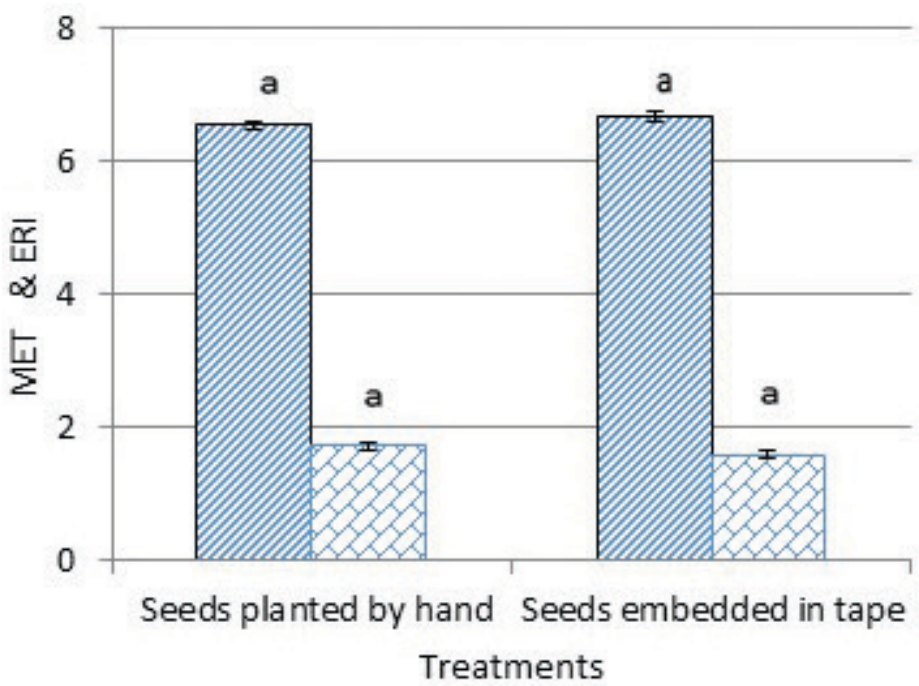

$\operatorname{MET}(d)$

ERI (seedlings ${ }^{-1} \mathrm{~d}^{-1} 20$ inches)

Figure 2. Mean emergence time (MET) and emergence rate index (ERI) of corn seed embedded in tape and seeds planted by hand under greenhouse conditions. Means with the same letter were not significantly different at the 0.05 probability level. (MET $=\frac{N_{1} T_{1}+N_{2} T_{2} \ldots N_{n} T_{n}}{N_{1}+N_{2} \ldots N_{n}} ; N_{1} \ldots .$. number of seedlings emerging since the time of previous count; $T_{1} \ldots . n$ : number of days after sowing) $\left(E R I=\frac{S_{t e}}{M E T} ; S_{t e}=\right.$ number of emerged seedlings per 20 inches; MET, mean emergence time).

seeds for each hybrid). The data from the repeated experiments were combined for analysis because there was no significant interaction between treatments and experiments.
Means were separated using Fisher's Protected LSD test at the $P \leq 0.05$ level. 


\section{SUMMARY}

There was no significant difference in the emergence percentage (data are not shown), MET, and ERI of corn seeds planted by hand and embedded in tape (Fig. 2). Results from this study demonstrate that uniformity of corn emergence was not affected by seed tape under greenhouse conditions.

\section{References}

Chancellor, W.J. 1969. Seed tape system for precision selection and planting small vegetable seeds. Trans. ASAE 12:876-879. doi:10.13031/2013.38976

Deppermann, K.L., B.J. Forinash, T. Frey, and M. McNabnay. 2013. Seed tape planter. U.S. Patent 20130152836 A1. Date issued: 20 June.

Karayel, D., and A. Ozmerzi. 2002. Effect of tillage methods on sowing uniformity of maize. Can. Biosyst. Eng. 44: 2.23-2.26.

Mateus, M. 2014. The use of a new technology of planting based on seed tape. http://www.gatesfoundation.org/(accessed 16 Mar. 2014). 